\title{
Tidevannsmodellen kan bidra til bedre psykiatrisk sykepleie
}

\section{Tidevannsmodellen viser hvordan sykepleiere kan gi god} sykepleie til pasienter som har psykiske lidelser, og hjelpe dem til å finne konstruktive måter å løse livets utfordringer på.

Johanne Temine Punsvik

Universitetslektor

Institutt for helse- og omsorgsfag, UiT Norges arktiske universitet, campus Narvik

Gabriele Kitzmüller

Førsteamanuensis

Institutt for helse- og omsorgsfag, UiT Norges arktiske universitet

Psykisk helsearbeid

Recovery

Tidevannsmodellen

Sykepleieteori

\section{Hovedbudskap}

I denne artikkelen presenterer vi Phil Barkers tidevannsmodell, som kan være en veiviser i recovery-orientert psykisk helsearbeid.

Recovery ved rusproblemer og psykisk uhelse er et perspektiv og en filosofi som tar utgangspunkt $i$ at bedring er en prosess med startpunkt i menneskers egne ønsker, ressurser og verdier. Recovery har som mål at den enkelte skal leve et meningsfullt liv med håp og glede til tross for begrensningene den psykiske uhelsen skaper (1). 
Både fagpersoner og brukerorganisasjoner fremholder at recovery og personers individuelle utfordringer skal være utgangspunktet for hjelp i psykiske helsetjenester (2-4).

Denne artikkelen vil presentere Phil Barkers tidevannsmodell som et teoretisk rammeverk for recovery-orientert sykepleie i psykisk helsearbeid. Modellen tilbyr begreper og strukturer som kan hjelpe sykepleiere å legge vekt på personers unike veier til bedring.

\section{Modellen er en ny måte å samtale på}

Vi ble oppmerksomme på Phil Barkers teori gjennom vår gode kollega professor Lena Wiklund Gustin, som har sin hovedstilling ved Mälardalens Högskola i Sverige. Hun og hennes kolleger har i flere år brukt Barkers modell i undervisningen av studenter ved videreutdanning i psykisk helse.

Gustin har erfart at modellens bruk i praksis skaper engasjement, og at den er en ny måte å samtale med pasienter på. Med bakgrunn i våre egne erfaringer med pasienter i psykiske helsetjenester, vil vi presentere våre tanker om hvordan denne modellen kan anvendes i praksis.

\section{Vi trenger ulike kunnskapstradisjoner}

Mennesker har til alle tider gjort det de må gjøre for å komme seg gjennom vanskeligheter i livet, og ikke alle recoveryprosesser krever en involvering av fagfolk. Derimot vil personer som opplever større utfordringer enn deres egen kapasitet til bedring, ta kontakt med helsetjenester innen rus og psykisk helse. Pasienter og brukere er derfor avhengig av kvaliteten på hjelpen som helsepersonell tilbyr.

\section{三 «Forståelsen av psykisk lidelse har variert gjennom historien.»}

Hvilket tilbud vi møter pasienter med har sin bakgrunn i

hvilke forklaringsmodeller som legges til grunn for hva

psykisk uhelse er. Forståelsen av psykisk lidelse har variert

gjennom historien. På mange måter har den pendlet mellom

ytterpunkter hvor man ser på psykiske lidelser som sosialt

forankrede og kontekstuelle eller som biologisk og

psykologisk forstyrrede funksjoner (5). 
Gjennom mange tiår har det psykiatriske perspektivet hatt stor innflytelse på bakgrunn av medisinsk tradisjon og naturvitenskapelig forskning, som fors $\emptyset$ ker å påvise årsaker til avvik (6).

Andersen og medarbeidere (7) skriver om nittitallets erkjennelse av den psykiatriske forståelsen som en utilstrekkelig og hegemonisk tenkemåte og praksisform. Opptrappingsplanen (8) for psykisk helse talte for flere perspektiver og løftet frem at tverrfaglighet og brukermedvirkning er nødvendig i psykiske helsetjenester.

I dag ser vi at de fleste fagpersoner innen psykisk helsearbeid er enige om behovet for en grunnlagsforståelse som tar hensyn til helhet ved å vektlegge både biologiske, psykologiske og sosiale årsaker til psykiske problemer. Til tross for denne enigheten, mener vi at det medisinske perspektivet stadig veier tyngst både i strukturering av tjenesten og prioriteringer hos den enkelte fagperson.

\section{Vi samarbeider på tvers av fag}

$\varnothing$ nsket fra helsemyndigheter og fagpersoner om perspektivmangfold har ført til mer tverrfaglig samarbeid innen psykisk helsearbeid. Opptrappingsplanens (8) styring mot tverrfaglighet vises blant annet gjennom at videreutdanningen i psykiatrisk sykepleie nå er en tverrfaglig utdanning i psykisk helsearbeid.

\section{$\equiv$ ¿Vi trenger sykepleiere i psykisk helsearbeid som er tydelige i sin rolle.»}

Kirkevold (9) påpeker at tverrfaglighet forutsetter at yrkesgruppenes kompetanse er tydelig og kjent for alle parter. I mangfoldet av tjenester og profesjoner har det særegne bidraget til sykepleierne blitt mindre og mindre synlig. Vi trenger sykepleiere i psykisk helsearbeid som er tydelige i sin rolle, og som argumenterer for pasientens rett til å motta god sykepleie. Her mener vi at Phil Barkers tidevannsmodell kan være en veiviser.

\section{Phil Barker utviklet tidevannsmodellen}

Phil Barker er født i 1932, i Scotland. Barker var kunstner før han ble psykiatrisk sykepleier. Han er professor emeritus og underviser fortsatt. 
Sammen med sin kone Poppy Buchanan-Barker utforsket han hvilken hjelp som bidrar til at mennesker med psykiske problemer opplever bedring. Barkers utgangspunkt er fortellingene til personer som har erfart psykisk uhelse og deres levde liv (10).

\section{Mennesker er sine fortellinger}

Tidevannsmodellen legger til grunn at mennesker er sine fortellinger. Fortellingene er historiene pasienten forteller til seg selv og andre, som igjen er påvirket av historiene som andre forteller om dem (11). Den beste måten å få kunnskap om seg selv er å dele den med andre.

\section{$\equiv \ll \AA$ dele sin fortelling vil gi pasienten større selvinnsikt.»}

$\AA$ dele sin fortelling vil gi pasienten større selvinnsikt - hvem er jeg, og hva er viktig for meg? Barker er opptatt av å hjelpe mennesker til å eie sin egen fortelling om motgang og lidelse, slik at det ubevisste blir bevisst og at personen etter hvert kan forme en ny fortelling om seg selv.

\section{Tidevannet er en metafor for livet}

Havet er utgangspunktet for Barkers (12) bruk av tidevannet som metafor for livet. Tidevannet er i konstant bevegelse. Livet er som en reise på havet hvor disse skiftningene gir både farer og muligheter. Underveis kan personen møte stormer eller lide skipbrudd, og få behov for å loses til en trygg havn.

På samme måte kan vår helse og våre livsomstendigheter, og dermed også behovet for hjelp fra andre, variere gjennom livet. Mennesker er i kontinuerlige forandringsprosesser. Psykisk smerte og psykiske behov er en uunngåelig del av det å være menneske (10). Sorg, lidelse og kriser kan være en mulighet til endring og utvikling på nye områder.

\section{Hva er psykisk uhelse?}

Tidevannsmodellen anerkjenner at psykiske problemer må møtes med ulike teoretiske perspektiver (12). Barker (10) legger vekt på at psykisk uhelse er menneskets naturlige reaksjon på overveldende livsomstendigheter fremfor et utslag av psykologiske eller fysiologiske forstyrrelser. Barker (12) beskriver dette som «problems in living» eller «menneskelige livsproblem». 
De aller fleste som har behov for støtte på grunn av psykisk uhelse, erfarer at følelsesmessige belastninger, bekymring eller uro gjør det vanskelig å leve med seg selv, forholde seg til andre og at andre opplever det som vanskelig å leve med dem. Slike kriser kan gi ulike former for trusler.

\section{三 «Trusler som kommer innenfra, kan være følelser av verdiløshet, håpløshet eller at man hører anklagende stemmer. »}

Trusler som kommer innenfra, kan være følelser av verdiløshet, håpløshet eller at man hører anklagende stemmer. Trusler utenfra kan være stigmatisering, anklager, diskriminering eller overgrep (11).

\section{Sykepleierens oppgave i tidevannsmodellen}

Sykepleie er å være til stede for mennesker som går gjennom kriser, og hjelpe pasienten til å finne sin vei gjennom livsproblemene (12). Tidevannsmodellen legger vekt på personens opplevelse, mer enn personens atferd eller diagnose.

Sykepleierens oppgave er ikke å avdekke årsaker, men å utforske personens opplevelse, gjennom å lytte til personens livsfortelling (13). Arbeidet med livsfortellingen skal hjelpe pasienten til å bli kjent med seg selv.

\section{Sykepleieren skal minimere trusselen}

Sykepleieren skal skape det miljøet og aktivere mulighetene personen trenger for å få det bedre med seg selv og sine omgivelser (12). Psykisk smerte gir ofte en opplevelse av frykt og utrygghet. Sykepleie er å identifisere det som truer personens trygghet og sammen med pasienten søke etter hva som må gjøres for å minimere trusselen.

\section{Relasjonen mellom pasienten og sykepleieren er viktig}

Relasjonen mellom sykepleieren og pasienten har avgjørende betydning, både for å skape trygghet og for å være oppmerksom på alle endringer i personens tilstand. En hjelpende relasjon forutsetter at sykepleieren ikke tar styring over pasienten, men støtter personen i å finne mer konstruktive måter å løse livets utfordringer på enn tidligere (13). 


\section{Vi skal sette grenser}

At mennesker skal få bestemme over sitt eget liv er grunnleggende i tidevannsmodellen. Av og til kan det likevel være et skille mellom det personen ønsker akkurat nå og det han trenger for en varig bedring. Sykepleierens oppgave er også å sette gode grenser, slik at pasienten ikke skaper enda større problemer for seg selv (13).

\section{Verdigrunnlaget i tidevannsmodellen}

Verdigrunnlaget i tidevannsmodellen er beskrevet av Buchanan-Barker og Barker (14, 15) gjennom ti forpliktelser. Sykepleieren skal alltid legge verdiene til grunn for sitt arbeid. Vi vil her beskrive tre av forpliktelsene.

\section{Sykepleieren skal lytte til og verdsette personens stemme}

Den st $\varnothing$ rste forpliktelsen er at sykepleieren skal lytte til og verdsette personens stemme. Pasientens egen fortelling om sitt liv og sine utfordringer skal være sentral i sykepleierens arbeid for å hjelpe pasienten mot bedring.

Det betyr at om pasienten beskriver smerten ved å ha gjentatte brutte relasjoner til venner og kjærester som et gjennomgående tema i sin fortelling, skal sykepleieren være opptatt av relasjonsarbeid i samme grad som av kartlegging av aktiviteter i dagliglivet, altså ADL-funksjon (activities of daily living) eller medikamentjustering.

\section{$\equiv \ll$ Pasientens fortelling kan vise veien til problemløsning og håp.»}

I tidevannsmodellen ligger det en tanke om at pasientens fortelling ikke bare rommer det som har vært vondt og vanskelig, men også kan vise veien til problemløsning og håp. Derfor er det viktig at sykepleieren hjelper pasienten med å granske fortellingen.

\section{Sykepleieren skal utvikle ekte interesse for fortellingen}

En annen forpliktelse er at sykepleieren skal utvikle ekte interesse og nysgjerrighet for pasientens fortelling. Det er få mennesker som vil fortelle noe som helst, dersom ingen lytter. Å lytte er mer enn å være til stede. Sykepleieren må derfor vise virkelig interesse for å forstå den andre. 
Møtet mellom pasient og sykepleier må ha betydning for begge parter. Det betyr ikke at vi skal bli private eller utvikle vennskapsforhold, men at sykepleieren kan vise seg som et menneske som blir berørt både av pasientens vonde erfaringer og gode fremskritt.

\section{Sykepleieren skal være åpen og tydelig i sin kommunikasjon}

Den siste forpliktelsen vi vil trekke frem, er at sykepleieren skal være åpen og tydelig i sin kommunikasjon. Sykepleieren og pasienten skal være et team, og det krever tillit og åpenhet i relasjonen. Hjelpen skal ikke inneholde unødvendige overraskelser.

Her er noen eksempler: Dersom behandlere vurderer at pasienten kan ha nytte av ECT-behandling, skal pasienten få vite dette og slippe at hele personalgruppen vet at dette ligger i planene før det er foreslått for pasienten selv. Hvis pasienten forteller noe til sykepleieren som gjør at hun blir bekymret for om pasienten er klar for å reise ut til planlagt tid, så må sykepleieren formidle dette klart og tydelig.

\section{Gode verktøy i sykepleien}

Barker og Buchanan-Barker (11) har også laget en manual med konkrete hjelpemidler for å anvende verdiene i praksis. Verktøyene omfatter helhetlig vurdering, trygghetsplan, samtaler på tomannshånd og gruppesamtaler.

\section{Pasientens tilsynsbehov må kartlegges}

Barker og Buchanan-Barker (11) foreslår at en av de første samtalene mellom sykepleier og pasient skal handle om kartlegging av pasientens tilsynsbehov. Sykepleieren skal hjelpe pasienten med å identifisere de truslene som gir risiko for at personen skader seg selv eller andre.

\section{三 «Trusler kan være alt fra følelsesmessige vanskeligheter, krangel med kjæresten, indre stemmer eller press fra Nav.»}

Trusler kan være alt fra følelsesmessige vanskeligheter, krangel med kjæresten, indre stemmer eller press fra Nav. Pasienten angir på en skala fra o-10 både sin egen opplevelse av trusler, tro på egen evne til å endre situasjonen og tiltro til sykepleierens hjelp. Sykepleieren gir på samme måte sin vurdering av dagens situasjon. 


\section{En trygghetsplan skal gi trygghet}

Videre i samtalen setter sykepleieren søkelys på hvordan pasienten tidligere har mestret liknende utfordringer. Dette arbeidet er det Barker og Buchanan Baker (11) kaller en trygghetsplan. Sammen kan pasienten og sykepleieren utforske hva som har hjulpet tidligere; $₫ \varnothing v n$, avspennings $\varnothing v e l s e r$, samtaler eller dataspill? Sykepleierens mål med trygghetsplanen er å finne det som gir pasienten større opplevelse av indre og ytre trygghet.

\section{Sykepleieren gjør en helhetlig vurdering}

Den helhetlige vurderingen retter seg mot personens livsfortelling (11). Gjennom ulike spørsmål kartlegger sykepleieren hva som er viktig for personen, som for eksempel mennesker, ting og tanker. Kartleggingen skal også avdekke hvordan personen har det nå og fortellinger om hvordan det ble slik.

Eksempler på spørsmål sykepleieren stiller pasienten i en helhetlig vurdering er: «Hvem i din familie og omgangskrets er viktig for deg; hvilke tanker om livet er viktig for deg; hvordan var det alt begynte; hvordan har det påvirket deg og dine relasjoner til andre; hva er ditt største problem nå?». Sykepleieren oppfordrer pasienten til å skrive ned svarene med egne ord.

\section{$\equiv \ll$ «ykepleieren bruker ordene pasienten selv velger.»}

Når en kvinne i sin fortelling sier slikt som «senga tok meg første gang da jeg var 16 år», kan sykepleieren spørre videre: «Kan du fortelle mer om hvordan du opplevde at senga tok deg?». Helsepersonell har lett for å oversette pasienters utsagn til medisinske uttrykk som depresjon eller alvorlig nedstemthet. I tidevannsmodellen ligger det et $\varnothing$ nske om å verdsette personens språk gjennom at sykepleieren bruker ordene pasienten selv velger.

\section{Samtaler på tomannshånd}

I daglige samtaler på tomannshånd tar sykepleieren utgangspunkt i den helhetlige vurderingen, og utforsker hvordan pasienten har det akkurat i dag. Sykepleieren skal konsentrere seg om personens bedringsprosess.

\section{三 «Når pasienten forteller, søker sykepleieren å identifisere de positive endringene hos pasienten.»}


Når pasienten forteller, søker sykepleieren å identifisere og holde frem de positive endringene hos pasienten, også de veldig, veldig små. Eksempel på dette kan være at sykepleieren i samtalen sier: «Så flott at du ringte arbeidsgiveren din i dag, Ole. For en uke siden sa du at den telefonsamtalen var helt umulig å få til».

\section{Grupper med ulike temaer}

Tidevannsmodellen fremholder at mennesker er grunnleggende relasjonelle (11). Mennesker blir styrket både av å se at andre kan ha like erfaringer, og at de selv kan bety noe $i$ andre sine liv.

Barker og Buchanan Barker (11) anbefaler at pasienter deltar i ulike grupper som legger til rette for læring og samhandling. I enkelte grupper snakker pasientene om hverdagslige temaer, med spørsmål som «Hva liker du å gjøre når du skal slappe av?», mens andre grupper kan ha undervisning om for eksempel kosthold og psykisk helse eller informasjon fra brukerorganisasjoner.

\section{Erfaringer fra praksis}

Tidevannsmodellen har blitt iverksatt ved flere avdelinger i land som Irland (16), Storbritannia (17), Canada (18) og Tyrkia (19). Studier som utforsket tidevannsmodellen i praksis, indikerer at det er reduksjon i voldshendelser, selvskading og bruk av tvang $(17,20)$.

\section{三 «Sykepleiere erfarer at å jobbe ut ifra tidevannsmodellen styrker samarbeidet mellom sykepleier og pasient.»}

Sykepleiere erfarer at å jobbe ut ifra tidevannsmodellen styrker samarbeidet mellom sykepleier og pasient og gir en sterkere opplevelse av å gjøre en forskjell i pasientens liv (16, 21). $\AA$ arbeide med pasientens livsfortelling kan forbedre praksis og fremme pasienters eierskap i behandling (18).

Henderson (22) viser at personalet endrer sitt syn på behandlingen fra forvaring til recovery, og pasientene opplever $\varnothing \mathrm{kt}$ autonomi. I rusbehandling skaper implementering av modellen positiv identifisering, vekst, mestring, selvbeherskelse og opplevelse av sosial st $\varnothing$ tte hos pasientene (19). 


\section{Modellen kan bidra til god sykepleie}

Vi mener tverrfaglighet og perspektivmangfold er nødvendig for å hjelpe mennesker med psykisk uhelse og rusproblematikk. Sykepleiere har en viktig funksjon i recovery-orientert psykisk helsearbeid, og vi vil hevde at tidevannsmodellen kan sette søkelys på og gi retning for god sykepleie.

Verdigrunnlaget i modellen plasserer personen i sentrum og anerkjenner menneskers erfaringer som betydningsfulle i recovery-prosesser. På bakgrunn av verdiene tilbyr modellen utforskende og risikovurderende redskaper som vi tror kan være et bidrag i god sykepleie til pasienter med psykiske utfordringer.

\section{Referanser}

1. Slade M, Hayward M. Recovery, psychosis and psychiatry: research is better than rhetoric. Acta Psychiatr Scand. 2007;116(2):81-3.

2. Meld. St. nr. 26 (2014-2015). Fremtidens primærhelsetjeneste - nærhet og helhet. Oslo: Helse- og omsorgsdepartementet; 2015.

3. Karlsson B, Borg M. Recovery: tradisjoner, fornyelser og praksiser. Oslo: Gyldendal Akademisk; 2017.

4. Meld. St. nr. 19 (2014-2015). Folkehelsemeldingen Mestring og muligheter. Oslo: Helse- og omsorgsdepartementet; 2015.

5. Johannesen JO, Joa I. Moderne psykoseforståelse og konsekvenser for struktur og innhold i tjenestetilbudet. PsykOpp Nytt. 2015;(2).

6. Aarre TF. En mindre medisinsk psykiatri. Oslo: Universitetsforlaget; 2018.

7. Andersen AJW, Larsen IB, Ulland E. Bidrag til en ny praksis? Utvikling og forskning i psykisk helsearbeid ved Universitetet i Agder i perioden 2008-2013. Tidsskrift for psykisk helsearbeid. 2015;(O1):4-16.

8. Meld. St. nr. 25 (1996-1997). Åpenhet og helhet - Om psykiske lidelser og tjenestetilbudene. Oslo: Helse- og omsorgsdepartementet; 1997. 
9. Kirkevold M. Trenger vi sykepleieteori? Tidsskriftet Sykepleien. 2019(1):58-61.

10. Brookes N. Phil Barker: Tidal model of mental health recovery. I: Marriner-Tomey A, Alligood MR, red. Nursing theorists and their work. 7 utg. Maryland Heights: Mosby Elsevier; 2010.

11. Barker P, Buchannan- Barker P. The tidal model mental health, reclamation and recovery. Tidal. Recovery and Reclamation. 2007. Tilgjengelig fra: http://www.tidalmodel.com/tidal\%2omanual.html (01.01.2019).

12. Barker P. The tidal model. J Psychosoc Nurs Ment Health Serv. 2002;40(7):42-50.

13. Gustin LW, Lindwall L. Omvårdnadsteorier i klinisk praxis: Natur och kultur; 2012.

14. Buchanan-Barker P, Barker PJ. The ten commitments: a value base for mental health recovery. J Psychosoc Nurs Ment Health Serv. 2006;44(9):29-33.

15. Buchanan-Barker P, Barker PJ. The Tidal Commitments: extending the value base of mental health recovery. Journal of Psychiatric and Mental Health Nursing. 2008;15(2):93-100.

16. O'Donovan A. Patient-centred care in acute psychiatric admission units: reality or rhetoric? J Psychiatr Ment Health Nurs. 2007;14(6):542-8.

17. Gordon W, Morton T, Brooks G. Launching the Tidal Model: evaluating the evidence. J Psychiatr Ment Health Nurs. 2005;12(6):703-12.

18. Brookes N, Murata L, Tansey M, Brookes N. Tidal waves: Implementing a new model of mental health recovery and reclamation. Can Nurse. 2008;104(8):22-7.

19. Savaşan A, Çam O. The effect of the psychiatric nursing approach based on the Tidal Model on coping and selfesteem in people with alcohol dependency: a randomized trial. Arch Psychiatr Nurs. 2017;31(3):274-81.

20. Fletcher E, Stevenson C. Launching the Tidal Model in an adult mental health program. Nurs Stand. 2001;15(49):336. 
21. Cook NR, Phillips BN, Sadler D. The tidal model as experienced by patients and nurses in a regional forensic unit. J Psychiatr Ment Health Nurs. 2005;12(5):536-40.

22. Henderson J. How the tidal model was used to overcome a risk-averse ward culture. Mental Health Practice. 2013;17(1):34-7. 